\title{
Effect of macrophage migration inhibitory factor on inflammatory cytokines and fibrogenic gene expression in human RPE cells
}

\author{
DONG QIN $^{1}$, YANRONG JIANG ${ }^{2}$ and XUEMIN JIN ${ }^{1}$ \\ ${ }^{1}$ Henan Eye Institute, Henan Provincial Eye Hospital, People's Hospital of Henan Province, Zhengzhou, Henan 450003; \\ ${ }^{2}$ Department of Ophthalmology, People's Hospital of Peking University, Beijing 100044, P.R. China
}

Received July 14, 2018; Accepted April 24, 2019

DOI: $10.3892 / \mathrm{mmr} .2019 .10277$

\begin{abstract}
Proliferative vitreoretinopathy (PVR) is a vision-threatening disease. It is also a common complication resulting from surgery to correct rhegmatogenous retinal detachment. Proliferation and migration of retinal pigment epithelial (RPE) cells and the secretion of extracellular matrix molecules play an important role in the formation of the preretinal membrane in PVR patients. Furthermore, upregulated expression of inflammatory cytokines within the vitreous or subretinal fluid of patients experiencing vitreoretinal disorders may aggravate the inflammatory response and be involved in the development of PVR. PVR is triggered by many inflammatory cytokines and growth factors. Macrophage migration inhibitory factor (MIF), an inflammatory cytokine, is upregulated in the vitreous in PVR patients. However, there is little known concerning the connection between MIF and the expression of inflammatory cytokines, interleukin-6 (IL-6) and monocyte chemotactic-1 (MCP-1), and the fibrogenic gene, collagen I, in human RPE cells. Cell proliferation, migration, and expression of IL-6, MCP-1 and collagen I were assessed using an MTT assay, a Transwell assay, real-time PCR analysis and ELISA kits. Western-blot analysis was used to detect phosphorylation of p38 mitogen activated protein kinase (MAPK) and extracellular signal-regulated kinase (ERK) signaling pathways. The data revealed that MIF promoted the proliferation, migration and expression of IL-6, MCP-1 and collagen I, and phosphorylation of p38 and ERK signaling pathways in RPE cells in vitro. These findings suggest that MIF plays a proinflammatory and profibrotic role in the development of PVR.
\end{abstract}

Correspondence to: Dr Dong Qin or Dr Xuemin Jin, Henan Eye Institute, Henan Provincial Eye Hospital, People's Hospital of Henan Province, 7 Weiwu Road, Zhengzhou, Henan 450003, P.R. China

E-mail: qdzxj888@126.com

E-mail: xueminjin888@163.com

Key words: macrophage migration inhibitory factor, interleukin-6, monocyte chemotactic-1, collagen I, proliferative vitreoretinopathy, human retinal pigment epithelial cells

\section{Introduction}

Proliferative vitreoretinopathy (PVR) most commonly occurs as a complication in rhegmatogenous retinal detachment and is often the reason for the failure of this type of surgery $(1,2)$. Retinal pigment epithelial (RPE) cells, macrophages, glial cells, fibroblasts and various extracellular matrix molecules are the main components of the fibrotic membrane in PVR (3). This fibrotic membrane can contract, which can cause either a new retinal detachment or the failure of surgery. Moreover, the inflammation response and the proliferation and differentiation of RPE cells might be aggravated by the high levels of inflammatory factors in the vitreous of patients with vitreoretinal disorders (4-7). PVR is triggered by many cytokines, including interleukin-6 (IL-6), monocyte chemotactic protein-1 (MCP-1), tissue inhibitor of metalloproteinase-1 (TIMP-1) and intercellular cell adhesion molecule-1 (ICAM-1) (8-10).

Macrophage migration inhibitory factor (MIF) plays a vital role in immune and inflammatory responses. MIF is produced by various types of cells, such as endothelial cells, keratinocytes, anterior pituitary cells, monocytes and osteoblasts (11-16). MIF has been reported to be involved in fibrosis diseases $(17,18)$. Furthermore, MIF has been shown to contribute to the inflammatory phase of the wound healing process (19), and its expression has been immunohistochemically detected in the iris, cornea, retina, and ciliary body $(20,21)$.

Previous studies have illustrated that the expression of MIF in the vitreous is higher in PVR patients compared to that noted in control groups (22). In addition, MIF activates the mitogen activated protein kinase (MAPK) signaling pathway in human ectopic endometrial stromal cells (23). However, little is known concerning the correlation between MIF and the expression of IL-6, MCP-1 and collagen I in human RPE cells. In the present study, the role of MIF was investigated in regards to the regulation of the expression of IL-6, MCP-1 and collagen I as well as the potential signaling mechanism.

\section{Materials and methods}

Reagents. Recombinant human MIF was purchased from EMD Millipore. Anti-p-p38, p38, anti-p-ERK and ERK were obtained from Cell Signaling Technology (Danvers, MA). MIF inhibitor ISO-1 was obtained from Abcam (Cambridge, MA, USA). P38 inhibitor SB203580 and ERK inhibitor PD98059 
were obtained from Sigma-Aldrich/Merck KGaA. Collagen I, IL-6, and an MCP-1 enzyme-linked immunosorbent assay kit (ELISA) were obtained from Abcam (Cambridge, MA, USA).

Cell culture. Human RPE cells (ARPE-19; CRL-2302) were purchased from the American Type Culture Collection (ATCC; Manassas, VA, USA). The cells were cultured in Dulbecco's modified Eagle's Medium (DMEM; Gibco, Thermo Fisher Scientific, Inc.) supplemented with $10 \%$ fetal bovine serum (FBS; Gibco, Thermo Fisher Scientific, Inc.) in a humidified incubator at $37^{\circ} \mathrm{C}$ in $5 \% \mathrm{CO}_{2}$.

Cell proliferation assay. MTT [3-(4,5-dimethylthiazol2-yl)-2,5-diphenyltetrazolium bromide] was used to measure cell proliferation. Cells $\left(1 \times 10^{4}\right)$, grown in a 96-well plate for $24 \mathrm{~h}$, were cultured in DMEM supplemented with $1 \%$ FBS $(12 \mathrm{~h})$ and then stimulated with recombinant MIF for an additional $48 \mathrm{~h}$. MTT reagent was added to the culture medium, and the cells were incubated for an additional $4 \mathrm{~h}$ in a $37^{\circ} \mathrm{C}$ atmosphere. Next, $100 \mu \mathrm{l}$ of dimethyl sulfoxide (DMSO) was added to each well to dissolve the formed formazan crystals. Absorbance $(540 \mathrm{~nm})$ was measured using a microplate reader.

Cell migration assay. A Boyden chamber was used to measure migration of the RPE cells. The trypsinised RPE cells were placed in the upper chamber. FBS (10\%), with or without a concentration of $50 \mathrm{ng} / \mathrm{ml} \mathrm{MIF}$, was then placed in the bottom chamber. The cells were fixed in $4 \%$ paraformaldehyde and stained with crystal violet after $6 \mathrm{~h}$ of incubation. A cotton swab was used to swab away the non-migrated cells in the upper chamber. Migratory cells that moved through the filter towards the lower surface were counted with a cell counter in three fields per filter under a fluorescence microscope (magnification, x200).

Reverse transcription-quantitative PCR (RT-qPCR). In the presence or absence of pretreatment with PD98059, SB203580 and ISO- 1 for $30 \mathrm{~min}$, the cells $\left(1 \times 10^{6}\right)$ were collected after $24 \mathrm{~h}$ of incubation with MIF. Total RNA was extracted using a TRIzol kit (Invitrogen; Thermo Fisher Scientific, Inc.) according to the manufacturer's protocol. The cDNA was synthesized using a RevertAid First Strand cDNA Synthesis kit (Fermentas; Thermo Fisher Scientific, Inc.). RT-qPCR was measured using a detector (Bio-Rad Laboratories, Inc.). The PCR solution contained 12.5 $\mu$ 1 Maxima SYBR Green qPCR Master Mix (Fermentas; Thermo Fisher Scientific, Inc.), specific primers $(0.3 \mu \mathrm{M}$ each $)$, and $2.5 \mu \mathrm{l}$ cDNA with a final volume of $25 \mu \mathrm{l}$. The PCR primers were as follows: Human collagen I forward, 5'-TGGTGGTTATGACTTTGGTTACGAT-3 and reverse, 5'-TGTGCGAGCTGGGTTCTTTCTA-3'; human IL-6 forward, 5'-TGGCTGAAAAAGATGGATGCT-3' and reverse 5'-TCTGCACAGCTCTGGCTTGT-3'; human MCP-1 forward, 55-CTCATAGCAGCCACCTTCATTC-3 and reverse, 5'-TCA CAGCTTCTTTGGGACACTT-3'; human GAPDH forward, 5'-TGTTCGACAGTCAGCCGCAT-3' and reverse, 5'-ACTCCG ACCTTCACCTTCCC-3'. The reaction conditions for amplifying DNA were $95^{\circ} \mathrm{C}$ for $10 \mathrm{~min}$, followed by 40 cycles of $95^{\circ} \mathrm{C}$ for $15 \mathrm{sec}, 61^{\circ} \mathrm{C}$ for $30 \mathrm{sec}$, and $72^{\circ} \mathrm{C}$ for $30 \mathrm{sec}$. The mRNA expression was normalized to the expression of glyceraldehyde 3-phosphate dehydrogenase (GAPDH), and it was calculated using the following formula: Fold change $=2^{-\Delta \Delta \mathrm{Cq}}$ (24).
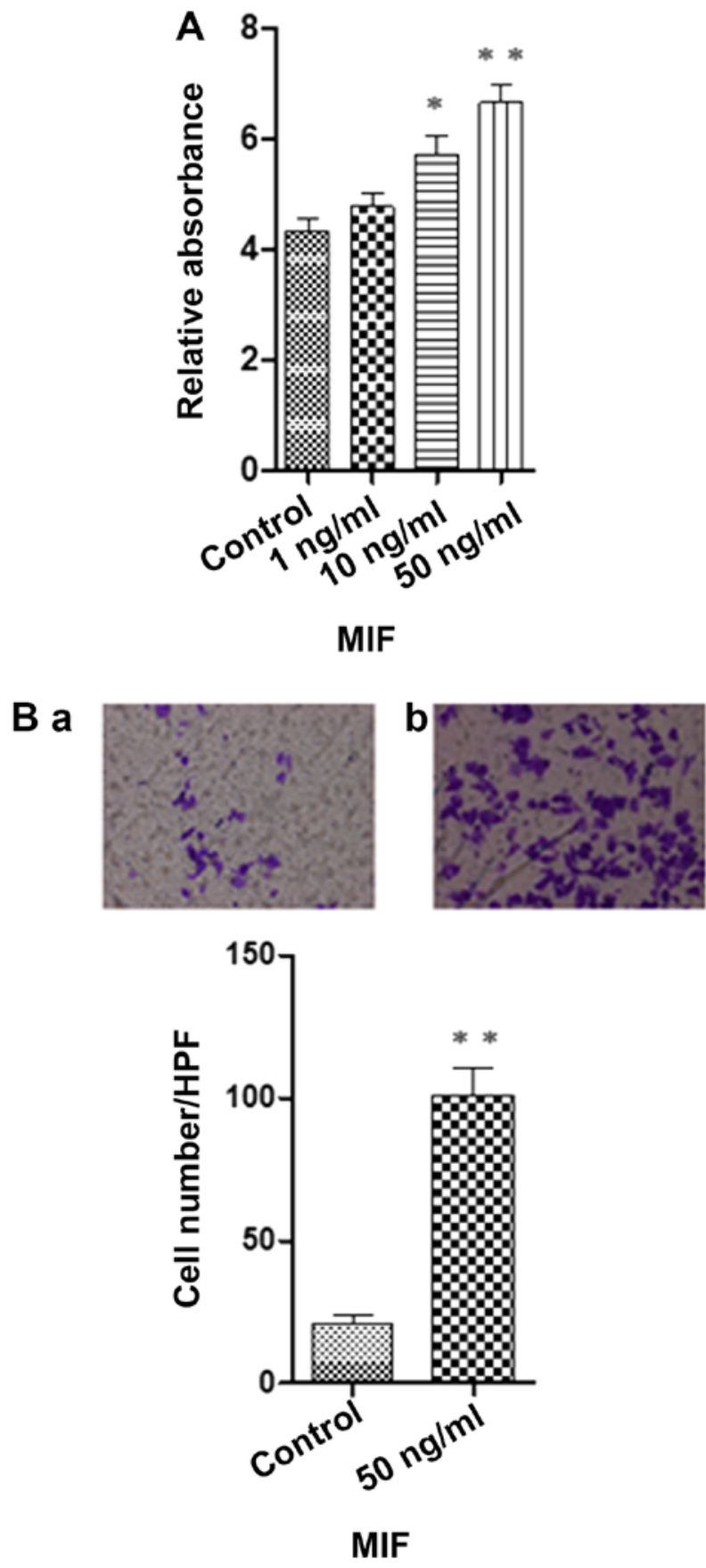

Figure 1. Effect of MIF on the proliferation of RPE cells was assessed by MTT study. (A) RPE cell proliferation was performed with MTT after $48 \mathrm{~h}$ of incubation with MIF [0 (control), 1,10 and $50 \mathrm{ng} / \mathrm{ml}$ ). Cell proliferation was increased in MIF-treated cells. (B) RPE cell migration was measured using a Transwell assay (a, control; b, $50 \mathrm{ng} / \mathrm{ml}$ MIF; x200 magnification). The mean number of migrated RPE cells was counted. The number of migrated RPE cells per high power field (HPF) is shown. ${ }^{*} \mathrm{P}<0.05$ and ${ }^{* *} \mathrm{P}<0.01$ vs. the untreated control. Data represent the mean $\pm \mathrm{SD}$ of three independent experiments. MIF, macrophage migration inhibitory factor.

Western blot analysis. Western blot was performed for analysis as previously described (25). In brief, protein samples were separated by electrophoresis on 10\% SDS-PAGE gels, transferred to PVDF membranes and then processed for analysis using an enhanced chemiluminescence detection system (Amersham). The primary antibodies were used at the following dilutions: Anti-p-p38 (Cell Signaling Technology; 9216; 

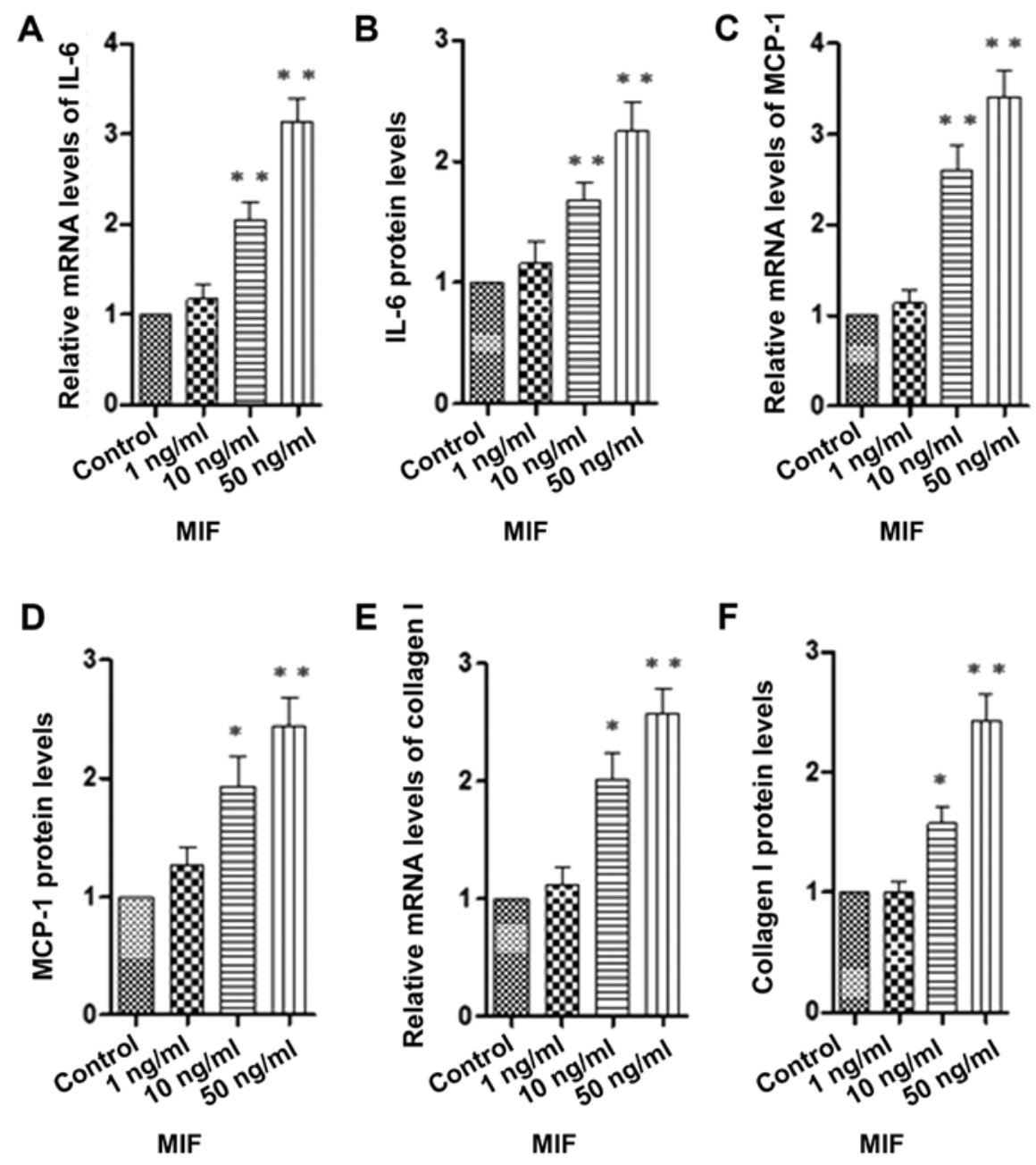

$\mathbf{F}$

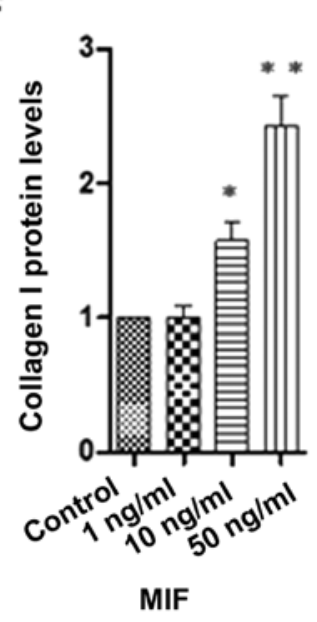

Figure 2. MIF promotes expression of IL-6, MCP-1 and collagen I in RPE cells in a dose-dependent manner. The expression of IL-6, MCP-1 and collagen I in RPE cells was determined using real-time PCR and ELISA kits. MIF at concentrations of 10 and $50 \mathrm{ng} / \mathrm{ml}$ significantly increased IL-6 (A and B), MCP-1 $(\mathrm{C}$ and $\mathrm{D})$ and collagen I (E and F) mRNA and protein levels, respectively, in RPE cells. Data represent the mean \pm SD of three independent experiments. ${ }^{*} \mathrm{P}<0.05$ and ${ }^{* *} \mathrm{P}<0.01$ vs. the untreated control. MIF, macrophage migration inhibitory factor; IL-6, interleukin-6; MCP-1, monocyte chemotactic-1.

1:2,000), anti-p38 (Cell Signaling Technology; 9212; 1:1,000), anti-p-ERK (Cell Signaling Technology; 9106; 1:2,000) and anti-ERK (Cell Signaling Technology; 4696; 1:1,000).

Enzyme-linked immunosorbent assay (ELISA). After the human RPE cells were treated, the conditioned medium was collected. IL-6 (ab46027), MCP-1(ab100586) and collagen I (ab210966) ELISA kits (Abcam), utilizing a sandwich two-site immunoassay, were applied to test the IL-6, MCP-1 and collagen I content in the medium.

Statistical analysis. All data are expressed as means \pm standard deviation (SD) and analysed with SPSS 17.0 (SPSS, Inc.). One-way analysis of variance followed by Tukey's test was used for statistical analysis, and $\mathrm{P}<0.05$ was considered to be indicative of a statistically significant result.

\section{Results}

MIF enhances human RPE cell proliferation and migration. The effects of MIF on the proliferation of RPE cells were examined using an MTT assay. In the cell proliferation assay, the cells were incubated with various concentrations of MIF
[0 (control), 1, 10 and $50 \mathrm{ng} / \mathrm{ml}$ ] for $48 \mathrm{~h}$. MIF significantly increased RPE cell proliferation compared to that noted in the control group (Fig. 1A). In the cell migration assay, the RPE cells were placed in a modified Boyden chamber. The mean number of migrated cells in the MIF-treated (50 ng/ml) RPE cells was significantly higher than that of the control group (Fig. 1B).

MIF-induced expression of IL-6, MCP-I and collagen I. The RPE cells were stimulated with MIF $(0,1,10$ and $50 \mathrm{ng} / \mathrm{ml})$. The expression of IL-6, MCP-1 and collagen I was measured using real-time PCR and the relevant ELISA kits. The levels of IL-6, MCP-1 and collagen I in human RPE cells were measured after $24 \mathrm{~h}$ of incubation with various concentrations of MIF. Our results showed that MIF (10 and $50 \mathrm{ng} / \mathrm{ml}$ ) induced significant increases in the mRNA and protein levels of IL-6 (Fig. 2A and B), MCP-1 (Fig. 2C and D) and collagen I (Fig. 2E and F) in the RPE cells compared to the control group.

MIF stimulates the RPE cells via ERK and p-38 pathways. The RPE cells were stimulated with 0,10 and $50 \mathrm{ng} / \mathrm{ml} \mathrm{MIF}$, and the phosphorylation levels of ERK and p38 were detected using western blot analysis. MIF (10 and $50 \mathrm{ng} / \mathrm{ml}$ ) significantly 
A

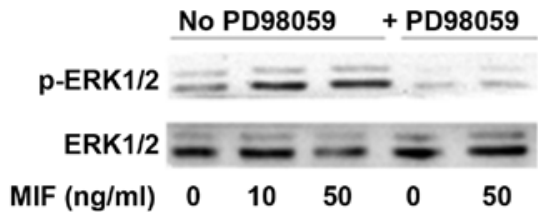

C

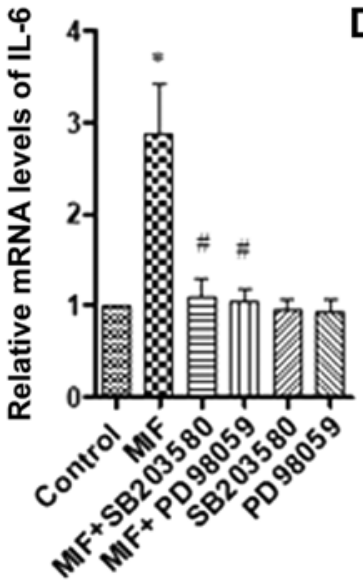

$\mathbf{F}$

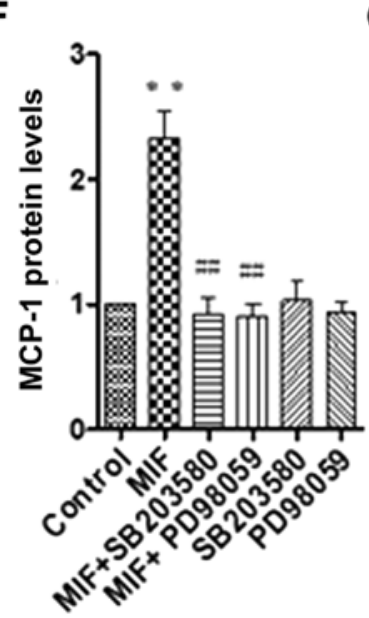

D

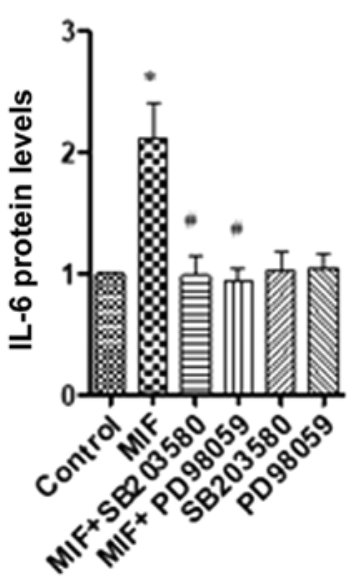

G

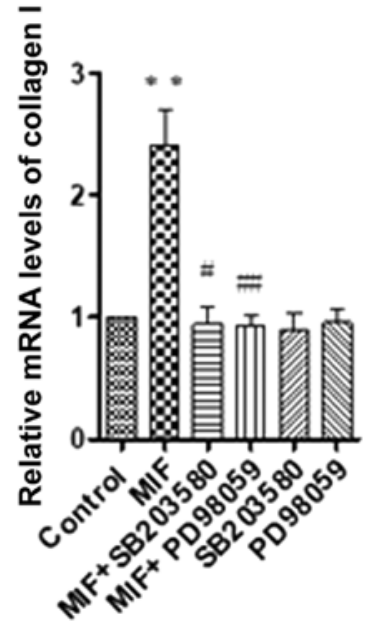

B

No SB203580 + SB203580

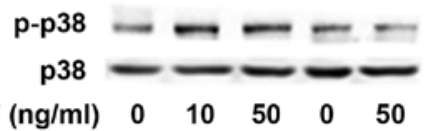

E

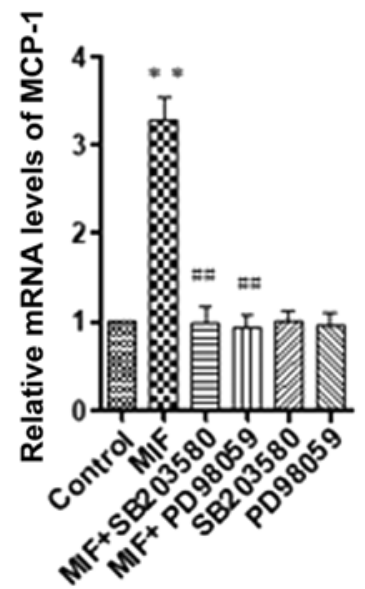

H

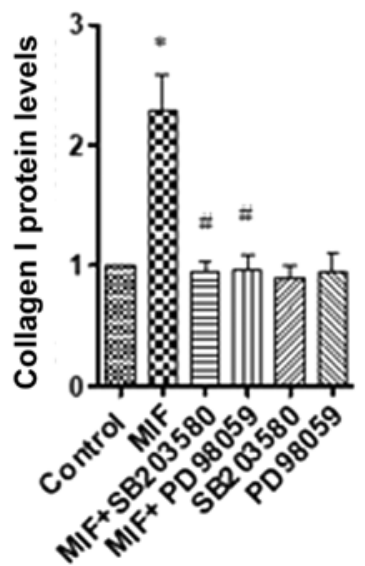

Figure 3. MIF stimulates RPE cells via the p-38 and ERK pathways. MIF increased ERK (A) and p38 (B) phosphorylation, and pretreatment with $50 \mu \mathrm{M}$ PD98059 and $50 \mu \mathrm{M}$ SB203580 suppressed MIF-induced activation of ERK and p38. RPE cells were stimulated with 50 ng/ml of MIF with or without pretreatment with $50 \mu \mathrm{M}$ of PD98059 and $50 \mu \mathrm{M}$ of SB203580 for $30 \mathrm{~min}$. After $24 \mathrm{~h}$ of incubation, the expression of IL-6 (C and D), MCP-1 (E and F) and collagen I $(\mathrm{G}$ and $\mathrm{H})$ was measured with real-time PCR and ELISA, respectively. Data are expressed as means \pm SD, and the experiments were performed independently three times. ${ }^{*} \mathrm{P}<0.05$ and ${ }^{* *} \mathrm{P}<0.01$ vs. the untreated control. ${ }^{\#} \mathrm{P}<0.05$ and ${ }^{\# \#} \mathrm{P}<0.01$ vs. the MIF-treated alone group. MIF, macrophage migration inhibitory factor; IL-6, interleukin-6; MCP-1, monocyte chemotactic-1.

activated the phosphorylation of ERK and p38. The phosphorylation of ERK and p38 was blocked by pretreatment with PD98059 and SB203580 (Fig. 3A and B). The levels of IL-6, MCP-1 and collagen I were determined using real-time PCR and the relevant ELISA kits.

Having found that MIF treatment activated the ERK and p38 signalling pathways in RPE cells, we then examined whether the activation of the ERK and p38 signalling pathways plays an important role in MIF-induced IL-6, MCP-1 and collagen I expression in RPE cells. The data showed that pretreatment with PD98059 and SB203580 for 30 min significantly blocked the MIF-induced expression of IL-6 (Fig. 3C and D), MCP-1 (Fig. 3E and F) and collagen I (Fig. 3G and H). In addition, pretreatment with MIF inhibitor ISO-1 for $30 \mathrm{~min}$ also significantly blocked the MIF-induced expression of
IL-6 (Fig. 4A and B), MCP-1 (Fig. 4C and D) and collagen I (Fig. 4E and F) in RPE cells.

\section{Discussion}

In patients with retinal detachment due to PVR, the cell proliferation, migration and secretion of extracellular matrix molecules, such as collagen I and fibronectin, are the main components of the fibrotic membrane. These membranes are formed during a fibrotic, inflammatory process involving cytokines, growth factors and cells, such as RPE cells. To prevent or treat PVR, anti-inflammatory (steroids) and cell-cycle inhibitors, such as daunorubicin, retinoic acid and 5-fluorouracil (5-FU), have been used, the latter particularly to decrease RPE cell proliferation (26-31). In the present study, 

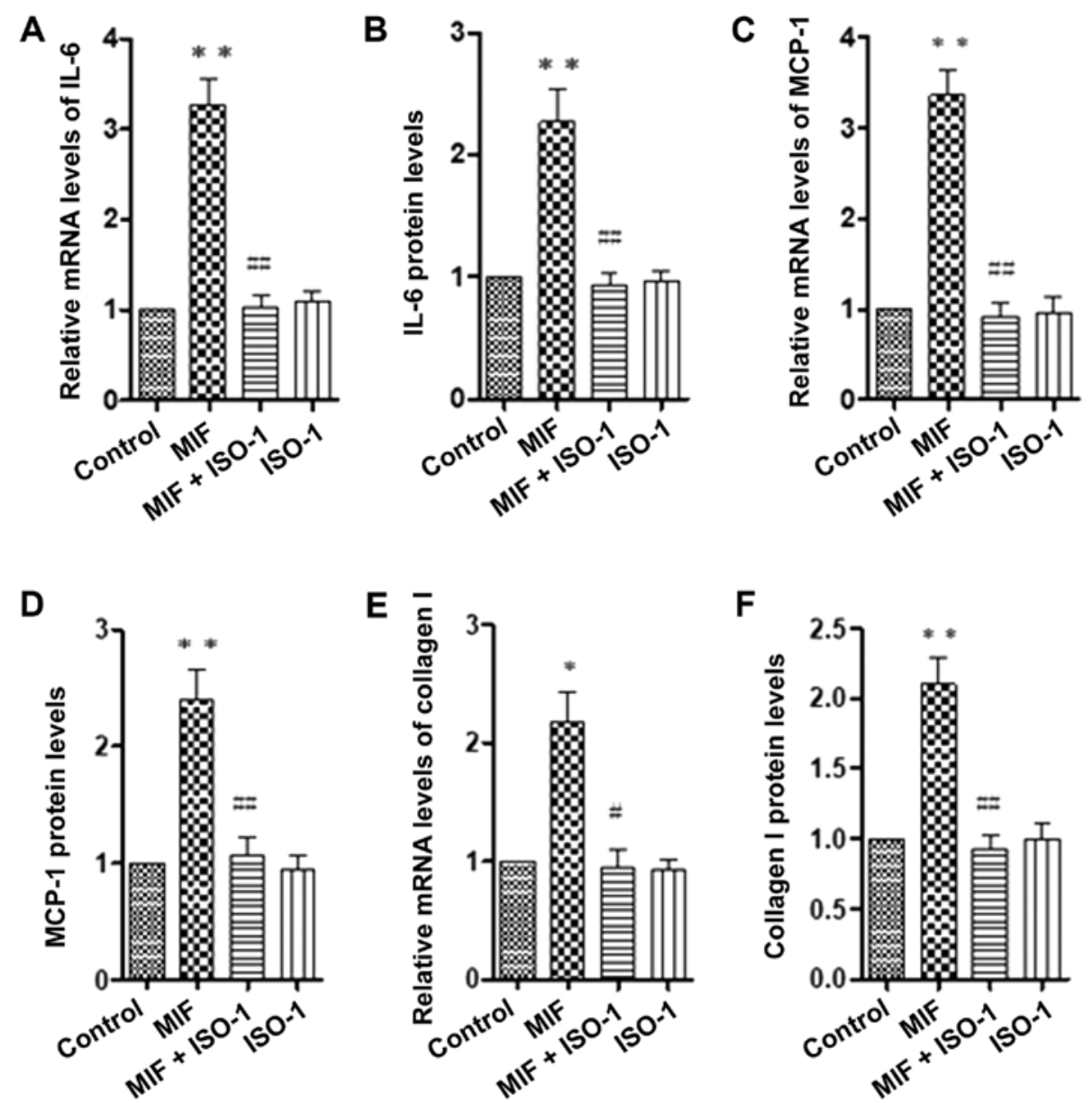

Figure 4. A specific inhibitor of MIF, ISO-1, downregulates the stimulating effects of MIF on RPE cells. The cells were treated with $50 \mathrm{ng} / \mathrm{ml} \mathrm{MIF}$ in the absence or presence of ISO-1 (50 $\mu \mathrm{M})$. The IL-6, MCP-1 and collagen I levels were determined using real-time PCR and ELISA kits. Preincubation of MIF with its inhibitor ISO-1 down-regulated IL-6 (A and B), MCP-1 (C and D), and collagen I (E and F) expression in the cells incubated with $50 \mathrm{ng} / \mathrm{ml} \mathrm{MIF} \mathrm{for}$ $24 \mathrm{~h}$. Data shown represent the mean $\pm \mathrm{SD}$ of three independent experiments. ${ }^{*} \mathrm{P}<0.05$ and ${ }^{* *} \mathrm{P}<0.01$ vs. the untreated control. ${ }^{\#} \mathrm{P}<0.05$ and ${ }^{\# \#} \mathrm{P}<0.01$ vs. the MIF-treated alone group. MIF, macrophage migration inhibitory factor; IL-6, interleukin-6; MCP-1, monocyte chemotactic-1.

the data showed that recombinant MIF induced cell proliferation, migration and secretion of collagen I, which suggests that MIF plays a profibrotic role in the development of PVR.

IL-6, a pleiotropic cytokine, is involved in immune and inflammatory reactions (32). Studies have shown IL-6 gene secretion and expression by cytokine-stimulated human RPE cells $(33,34)$. Furthermore, IL-6 was observed to induce chemokines and to enhance the recruitment of leukocytes in an animal model in vivo (35). The IL-6 levels in the vitreous were also found to be higher in a PVR group than that in a control group (9). MCP-1, as a representative chemokine, is the major determinant of macrophage recruitment to the site of tissue injury (36). In addition, MCP-1 stimulates human RPE cell migration, suggesting its role in PVR (37). The MCP-1 levels in the vitreous in PVR patients were found to be significantly higher compared to the control group (38). The above evidence suggests that inflammatory cytokines, such as IL-6 and MCP-1, play a vital role in the development of PVR. MIF regulates MCP-1 expression in the hepatocytes of injured liver tissue (39). MIF inhibitor decreases the expression of IL-6 in lipopolysaccharide (LPS)-activated microglial cells (40).

Furthermore, the level of MIF has been found to be upregulated in the vitreous in PVR patients (22). Recent results implicate MIF in the induction of epithelial-mesenchymal transition (EMT) and its related processes by oxidative stress in human RPE cells, and MIF was reported to regulate expression of EMT markers (41). In the present study, our data revealed that recombinant MIF increased the expression of IL-6 and MCP-1 in human RPE cells, which suggests that MIF plays a proinflammatory role in the development of PVR.

MIF activates the ERK and p38 MAPK signaling pathways in human ectopic endometrial stromal cells (23). However, the signaling mechanism of MIF in RPE cells remains unclear. The data of the present study indicated that MIF induced the activation of p38 and ERK in RPE cells, and pretreatment with p38 inhibitor SB203580, ERK inhibitor PD98059 and MIF inhibitor ISO-1 significantly decreased the MIF-induced expression of IL-6, MCP-1 and collagen I in human RPE cells.

In future research, the role of MIF should be investigated in animal models in vivo and knockdown of MIF receptor in RPE cells should be conducted. In addition, additional inflammatory factors should be investigated. These are the limitation of the present study. In summary, this study is the first to demonstrate that MIF induced the expression of IL-6, MCP-1 and collagen I through the $\mathrm{p} 38$ and ERK signaling pathways in RPE cells in vitro. Therefore, MIF may play a proinflammatory and profibrotic role in the development of PVR and may be a treatment option for PVR patients. 


\section{Acknowledgements}

Not applicable.

\section{Funding}

The present study was supported by the Department of Science and Technology of Henan Province (grant no. 162300410112).

\section{Availability of data and materials}

The datasets used during the present study are available from the corresponding author upon reasonable request.

\section{Authors' contributions}

DQ performed the experiments and wrote the paper. $\mathrm{XJ}$ designed the experiments. YJ analysed the data and revised the paper. All authors read and approved the final manuscript.

\section{Ethics approval and consent to participate}

Not applicable.

\section{Patient consent for publication}

Not applicable.

\section{Competing interests}

The authors declare that they have no competing interests.

\section{References}

1. Ishikawa K, He S, Terasaki H, Nazari H, Zhang H, Spee C, Kannan R and Hinton DR: Resveratrol inhibits epithelial mesenchymal transition of retinal pigment epithelium and development of proliferative vitreoretinopathy. Sci Rep 5: 16386, 2015.

2. Ryan SJ: The pathophysiology of proliferative vitreoretinopathy in its management. Am J Ophthalmol 100: 188-193, 1985.

3. Newsome DA, Rodrigues MM and Machemer R: Human massive periretinal proliferation. In vitro characteristics of cellular components. Arch Ophthalmol 99: 873-880, 1981.

4. Ricker LJ, Kessels AG, de Jager W, Hendrikse F, Kijlstra A and La Heij EC: Prediction of proliferative vitreoretinopathy after retinal detachment surgery: Potential of biomarker profiling. Am J Ophthalmol 154: 347-354.e2, 2012.

5. Ricker LJ, Altara R, Goezinne F, Hendrikse F, Kijlstra A and La Heij EC: Soluble apoptotic factors and adhesion molecules in rhegmatogenous retinal detachment. Invest Ophthalmol Vis Sci 52: 4256-4262, 2011.

6. Ricker LJ, Kijlstra A, de Jager W, Liem AT, Hendrikse F and La Heij EC: Chemokine levels in subretinal fluid obtained during scleral buckling surgery after rhegmatogenous retinal detachment. Invest Ophthalmol Vis Sci 51: 4143-4150, 2010.

7. Bromberg-White JL, Glazer L, Downer R,Furge K, BoguslawskiE and Duesbery NS: Identification of VEGF-independent cytokines in proliferative diabetic retinopathy vitreous. Invest Ophthalmol Vis Sci 54: 6472-6480, 2013

8. Hoerster R, Hermann MM, Rosentreter A, Muether PS, Kirchhof B and Fauser S: Profibrotic cytokines in aqueous humour correlate with aqueous flare in patients with rhegmatogenous retinal detachment. Br J Ophthalmol 97: 450-453, 2013.

9. Ricker LJ, Kijlstra A, Kessels AG, de Jager W, Liem AT, Hendrikse F and La Heij EC: Interleukin and growth factor levels in subretinal fluid in rhegmatogenous retinal detachment: A case-control study. PLoS One 6: e19141, 2011.
10. Symeonidis C, Papakonstantinou E, Androudi S, Georgalas I, Rotsos T, Karakiulakis G, Diza E and Dimitrakos SA: Comparison of interleukin- 6 and matrix metalloproteinase expression in the subretinal fluid and the vitreous during proliferative vitreoretinopathy: Correlations with extent, duration of RRD and PVR grade. Cytokine 67: 71-76, 2014.

11. David J: Delayed hypersensitivity in vitro: Its mediation by cell-free substances formed by lymphoid cell-antigen interaction. Proc Natl Acad Sci USA 56: 72-77, 1966.

12. Bloom B and Bennet B: Mechanism of a reaction in vitro associated with delayed-type hypersensitivity. Science 153: 80-82, 1966.

13. Nishihira J, Koyama Y and Mizue Y: Identification of macrophage migration inhibitory factor (MIF) in human vascular endothelial cells and its induction by lipopolysaccharide. Cytokine 10: 199-205, 1998.

14. Abe R, Shimizu T, Ohkawara A and Nishihira J: Enhancement of macrophage migration inhibitory factor (MIF) expression in injured epidermis and cultured fibroblasts. Biochimica Biophysica Acta 1500: 1-9, 2000.

15. Onodera S, Suzuki K, Matsuno T, Kaneda K, Kuriyama T and Nishihira J: Identification of macrophage migration inhibitory factor in murine neonatal calvariae and osteoblasts. Immunology 89: 430-435, 1996.

16. Bernhagen J, Calandra T, Mitchell RA, Martin SB, Voelter W, Manogue KR, Cerami A and Bucala R: MIF is a pituitary-derived cytokine that potentiates lethal endotoxaemia. Nature 365: 756-759, 1993.

17. Barnes MA, McMullen MR, Roychowdhury S, Madhun NZ, Niese K, Olman MA, Stavitsky AB, Bucala R and Nagy LE: Macrophage migration inhibitory factor is required for recruitment of scar-associated macrophages during liver fibrosis. J Leukoc Biol 97: 161-169, 2015.

18. Olivieri C, Bargagli E, Inghilleri S, Campo I, Cintorino $M$ and Rottoli P: Macrophage migration inhibitory factor in lung tissue of idiopathic pulmonary fibrosis patients. Exp Lung Res 42: 263-266, 2016.

19. Shimizu T, Nishihira J, Watanabe H, Abe R, Honda A, Ishibashi $\mathrm{T}$ and Shimizu $\mathrm{H}$ : Macrophage migration inhibitory factor is induced by thrombin and factor $\mathrm{Xa}$ in endothelial cells. J Biol Chem 279: 13729-12737, 2004.

20. Matsuda A, Tagawa Y, Matsuda H and Nishihira J: Identification and immunohistochemical localization of macrophage migration inhibitory factor in human cornea. FEBS Lett 385: 225-228, 1996.

21. Matsuda A, Tagawa Y, Yoshida K, Matsuda H and Nishihira J: Expression of macrophage migration inhibitory factor in rat retina and its immunohistochemical localization. J Neuroimmunol 77: 85-90, 1997.

22. Mitamura Y, Takeuchi S, Matsuda A, Tagawa Y, Mizue Y and Nishihira J: Macrophage migration inhibitory factor levels in the vitreous of patients with proliferative vitreoretinopathy. Am J Ophthalmol 128: 763-765, 1999.

23. Veillat V, Carli C, Metz CN, Al-Abed Y, Naccache PH and Akoum A: Macrophage migration inhibitory factor elicits an angiogenic phenotype in human ectopic endometrial cells and triggers the production of major angiogenic factors via CD44, CD74, and MAPK signaling pathways. J Clin Endocrinol Metab 95: E403-E412, 2010.

24. Livak KJ and Schmittgen TD: Analysis of relative gene expression data using real-time quantitative PCR and the 2(-Delta Delta C(T)) method. Methods 25: 402-408, 2001.

25. Chung BH, Kim JD, Kim CK, Kim JH, Won MH, Lee HS, Dong MS, Ha KS, Kwon YG and Kim YM: Icariin stimulates angiogenesis by activating the MEK/ERK-and PI3K/Akt/eNOSdependent signal pathways in human endothelial cells. Biochem Biophys Res Commun 376: 404-408, 2008.

26. Fekrat S, de Juan E Jr and Campochiaro PA: The effect of oral 13-cis-retinoic acid on retinal redetachment after surgical repair in eyes with proliferative vitreoretinopathy. Ophthalmology 102: 412-418, 1995.

27. Wiedemann P, Hilgers RD, Bauer P and Heimann K: Adjunctive daunorubicin in the treatment of proliferative vitreoretinopathy: Results of a multicenter clinical trial. Daunomycin Study Group. Am J Ophthalmol 126: 550-559, 1998.

28. Asaria RH, Kon CH, Bunce C, Charteris DG, Wong D, Khaw PT and Aylward GW: Adjuvant 5-fluorouracil and heparin prevents proliferative vitreoretinopathy: Results from a randomized, double-blind, controlled clinical trial. Ophthalmol 108: 1179-1183, 2001. 
29. Chang YC, Kao YH, Hu DN, Tsai LY and Wu WC: All-trans retinoic acid remodels extracellular matrix and suppresses laminin-enhanced contractility of cultured human retinal pigment epithelial cells. Exp Eye Res 8: 900-909, 2009.

30. Sadaka A and Giuliari GP: Proliferative vitreoretinopathy: Current and emerging treatments. Clin Ophthalmol 6: 1325-1333, 2012.

31. Chang YC, Hu DN and Wu WC: Effect of oral 13-cis-retinoic acid treatment on postoperative clinical outcome of eyes with proliferative vitreoretinopathy. Am J Ophthalmol 146: 440-446, 2008.

32. Kishimoto T: Interleukin-6: Discovery of a pleiotropic cytokine. Arthritis Res Ther 8 (Suppl 2): S2, 2006.

33. Kuppner MC, McKillop-Smith S and Forrester JV: TGF-beta and IL-1 beta act in synergy to enhance IL- 6 and IL- 8 mRNA levels and IL-6 production by human retinal pigment epithelial cells. Immunology 84: 265-271, 1995.

34. Holtkamp GM, Van Rossem M, de Vos AF, Willekens B, Peek R and Kijlstra A: Polarized secretion of IL-6 and IL-8 by human retinal pigment epithelial cells. Clin Exp Immunol 112: 34-43, 1998.

35. Romano M, Sironi M, Toniatti C, Polentarutti N, Fruscella P, Faggioni R, Luini W, van Hinsbergh V, Sozzani S, Bussolino F, et al: Role of IL- 6 and its soluble receptor in induction of chemokines and leukocyte recruitment. Immunity 6: 315-325, 1997.
36. Deshmane SL, Kremlev S, Amini S and Sawaya BE: Monocyte chemoattractant protein-1 (MCP-1): An overview. J Interferon Cytokine Res 29: 313-326, 2009.

37. Han QH, Hui YN, Du HJ, Zhang WJ, Ma JX and Wang SY: Migration of retinal pigment epithelial cells in vitro modulated by monocyte chemotactic protein-1: Enhancement and inhibition. Graefes Arch Clin Exp Ophthalmol 239: 531-538, 2001.

38. Mitamura Y, Takeuchi S, Yamamoto S, Yamamoto T, Tsukahara I, Matsuda A, Tagawa Y, Mizue Y and Nishihira J: Monocyte chemotactic protein-1 levels in the vitreous of patients with proliferative vitreoretinopathy. Jpn J Ophthalmol 46: 218-221, 2002.

39. Xie J, Yang L, Tian L, Li W, Yang L and Li L: Macrophage migration inhibitor factor upregulates MCP-1 expression in an autocrine manner in hepatocytes during acute mouse liver injury. Sci Rep 6: 27665, 2016.

40. Zhang Y, Gu R, Jia J, Hou T, Zheng LT and Zhen X: Inhibition of macrophage migration inhibitory factor (MIF) tautomerase activity suppresses microglia-mediated inflammatory responses. Clin Exp Pharmacol Physiol 43: 1134-1144, 2016.

41. Ko JA, Sotani Y, Ibrahim DG and Kiuchi Y: Role of macrophage migration inhibitory factor (MIF) in the effects of oxidative stress on human retinal pigment epithelial cells. Cell Biochem Funct 35: 426-432, 2017. 